\title{
Detecting the Gender Dimension of the Choice of the Teaching Profession Prior to the Economic Crisis and IMF (International Monetary Fund) Memorandum in Greece-A Case Study
}

\author{
Anna Asimaki ${ }^{1}$ \& Dimitris K. Vergidis ${ }^{1}$ \\ ${ }^{1}$ Department of Education, University of Patras, Patras, Hellas \\ Correspondence: Anna Asimaki, Department of Education, University of Patras, 26504 Patras, Hellas. Tel: \\ 30-261-099-7380. E-mail: asimaki@upatras.gr
}

Received: September 24, 2012

Accepted: November 16, 2012 Online Published: March 20, 2013

doi:10.5539/ies.v6n4p140

URL: http://dx.doi.org/10.5539/ies.v6n4p140

\begin{abstract}
The purpose of this research paper is the investigation of, and the sociological approach to, and interpretation of the attitudes of male and female students in the University Department of Primary Education (U.D.P.E.) at the University of Patras in Greece, before the enforcement of the IMF Memorandum, concerning the choice of the teaching profession and the corresponding scientific field of studies. In particular, we will be concerned with the following research questions: a) what are the attitudes of male and female students regarding the reasons for the choice of the particular scientific field and b) What is the influence of the gender of the male and female students of the U.D.P.E. at the University of Patras as far as the choice of studies in the particular scientific field is concerned. The most significant findings of the work reveal that in the particular University Department female students are overrepresented in percentage terms, a fact which demonstrates the 'feminizing' of the Department in question. It also became apparent that the educational and professional choice of the female students in the particular University department is guided by their gender, which directs their practice. Finally, the prospect of immediate and certain professional employment which studies in the field of teaching in Greece promised, before the appearance of the economic crisis and the enforcement of the austerity measures, emerged as the most significant factor in the choice of the teaching profession by both sexes.
\end{abstract}

Keywords: gender, habitus, field, teaching profession, symbolic violence

\section{Introduction}

The new social model, the so-called 'community of knowledge' which emerged out of the rapid, multidimensional and unpredictable technological changes in the second half of the 20th century, brought about, on the one hand, the shrinking of private space and, on the other a corresponding growth in public space (Moren, 2000:103; Tsaousis, 2009:131). At the beginning of the $21^{\text {st }}$ century, a redetermination of those spaces became evident, with the space of work taking precedence over the private space (of the home) (Evans, 2004:75). The above dichotomy, private space - home, public space - work, heralds the equalization of the two sexes and their disconnection from the social discrimination of public - male, private - female. The shrinking of the space of the home also entails the emergence of women as much in the field of education, as in the field of work. In addition, it entails the overthrow of the traditional, extended, cross generational family where the dominant model was structured around the securing of an income by the husband and the raising of the children exclusively by the mother. Today, in the western world, the contribution to the family income by both sexes is the rule (Dehaene, 1995:12; Tsaousis, 2010:136). Besides, it is no coincidence that European policy focuses on the work equality of the two sexes, the main objective of which is the competitiveness of the economy in the field of work (Grosser, 2009; Walby, 2004). Consequently, it is taken for granted in the economically developed societies that women participate in higher education as a result of socio-economic developments, but also as a result of the activity of feminist movements, particularly since the 1960's (Sianou-Kyrgiou, 2010:166). Women's access to higher education in the western world, mainly after the 1940's, resulted in their penetration into male dominated fields from which they had been excluded due to their lack of official academic qualifications (Witz, 1995:49. Arnot, 2006:369). However, despite the fact that today the presence of women is more apparent in the field of education and they participate in long term education, their position remains inferior in relation to the quality of their work, 
the scientific fields they choose to follow as well as to the occupation of and participation in positions with high salaries, great responsibility and social prestige (Meron, 2006:323-334; Giddens, 2002:433).

Today a transformation has taken place regarding the 'sex of work' in the sense that the reproduction of the gender hierarchy is not obvious, but it is carried out in a more refined manner (Nickel, 2010:288). So it seems that the hierarchical dichotomy masculinity - femininity remains powerful and exercises influence on professional choices and developments (Ready \& Ball, 2000; Sianou-Kyrgiou, 2010, p. 169).

Consequently, the division of labour is formed and structured hierarchically based on two principles: a) jobs for men and jobs for women - in other words a gender division of labour and b) male labour - superior and female labour - inferior. (Kergoat, 2006: 132; Maratou - Alibranti, 2007: 130).

Historically, in Greece, due to the traditional patriarchal structure of the greek family, the males had easier access to the education system than women in general, and in particular easier access to the higher levels. The continual socio-economic advancement of the country after the Second World War, the state education policy which enforced nine-year compulsory education, the modernization of ways of thinking and the predominance of the theory of human capital with its utilitarian results for state and society, led to continual improvements regarding the issue of the participation of greek women in the education system (Maratou-Alibranti, et al.. 2002; Kyridis, 2003:135). Today, the participation of women in higher education in Greece exceeds that of men. In the academic year 2008 - 2009, from a total of 171,882 male and female students at the country's universities, 65,564 were men and 104,318 women (Greek Statistical Service, 2008; Sianou-Kyrgiou, 2010:127). Nevertheless the statistical evidence in our country reveals that a gender differentiated internal distribution of choice in higher education still exists. Women are channeled into departments and schools which lead to the so-called 'female professions' with low status. This means that they become concentrated in the Social and Humanistic sciences and are far behind men in the other sciences (Sianou-Kyrgiou, 2007; 2010:168; Daraki, 2007: 93). Consequently, despite the social modernization of post war Greece and the penetration of women into the labour market, it appears that women's choice of studies and paid work is not exempt from traditional models and factors (Stratigaki, 2006:123).

Since the $19^{\text {th }}$ century the field of education in Greece has constituted one of the first acceptable fields of employment for women (Ziogou, 1986; Fournaraki, 1987; Varika, 1987; Avdela, 1990). Then, the teaching profession constituted the only acceptable choice for making a living, especially for those women who came from the lower social strata (Ziogou - Karastergiou, 1983:80-82; Kladouchou, 2010:195). Nevertheless, it appears that the choice of the teaching profession continues to be a convenient, suitable profession for women around the world, even today. In the western world, teaching took shape as paid female employment and research reveals that two thirds of teachers are women, and this proportion increases as we descend the educational grades (Apple \& Jungck, 2008:47). Male teachers appear to be in a minority in primary education in relation to their female colleagues as much in Europe as in the U.S.A., and also Australia (Wilson, 1997:5; Smith, 2004:16; Anagnostopoulou, et al. 2008).

The picture which emerges with regards to the teaching profession in Greece is similar. In the school year 2005-2006 only $31,9 \%$ of teachers in the country's Primary schools were men (Koulaidis, 2006:129; Anagnostopoulou et al. 2008). Consequently, the choice of the teaching profession in our country constitutes a 'permissible' profession for women, entirely connected with female nature (Reppa, 2000:461; Taki, 2009:140). In addition, the gender distribution in all of the country's University Pedagogical Departments follows the same pattern since 1998 , which means that approximately $80 \%$ of the total number of students in the Pedagogical Departments are women, a fact which confirms the characterization of the departments in question as of a 'female orientation' (Antoniou, 2002:233, 387; Georgiadis, 2009).

A study of the scientific bibliography revealed a lack of studies in Greece investigated in qualitative terms this gender professional choice, but also the percentile predominance of women in the scientific field of pedagogical studies (Kladouchou, 2010:129).

The purpose of the present work is the investigation of the attitudes of male and female students in the U. D. P. E. at the University of Patras regarding their choice of the teaching profession and their preference for the specific scientific field of studies, as well as the detection of gender differentiation in the reasons expressed for the choice of this scientific field.

The study begins with the theoretical framework, which makes use of Bourdieu's conceptual model. In order to interpret the attitudes of the male and female students regarding their choice of scientific field and profession, the concepts of 'habitus', field' and 'symbolic violence' will be used. Next, we will define the research questions 
and methodology used, and then go on to present and discuss the results. The paper ends with the study's conclusions.

\section{Theoretical Framework}

Bourdieu conceives of social reality in terms of objective relations between positions (Bourdieu \& Waqcuant, 1992:72). In other words, society is composed of a number of 'microcosms' which he calls 'fields'. One of those fields is the field of the 'Big and Small schools'. This particular field or 'market', of the 'Big and Small schools', is composed within the whole of the university institutions of a country. It concerns the 'admission' of a fundamental contradiction in the university field which distinguishes the Big and Small schools, and the bond between those who come from the higher social strata and those who come from the lower ones. This 'social border' allows the former to pass with ease through the big door of the 'Big Schools' (Bourdieu, 1989:188-189), while in contrast, the latter pass through the small door of 'commoner' Departments, such as the University Departments of Primary Education in Greece. In the greek university field the separation into Big and Small schools is connected with high demand, the high grades required in the university entrance exams, but also with the prospects for finding immediate employment in the corresponding professions in the labour market, elements which determine the prestige, status and reputation of each school (Sianou - Kyrgiou, 2010: 202-203). Nevertheless, these 'social worlds' or, to put it differently, 'the structured spaces of positions' such as, for example, the political, the artistic, the educational or the university field demand from those who hold a position within them, apart from the various kinds of capital which they must possess, a suitably shaped habitus which arises as a result of the socialization of the acting subjects (Bourdieu, 2000:157). Each field is also a field of fierce competition, there are stakes and interests and within each field a game takes place in which can participate only those who are equipped with the suitable habitus, which enables them to recognize the interests characteristic of the field each time, as well as the rules of the game (Bourdieu, 1994: 65-66).

According to Bourdieu, the two modes of existence of the 'social' as a fabricated relationship, are based, on the one hand, on the concept of the field (on the story that became an object) and, on the other hand, on the concept of habitus (on the story that became a body) (Bourdieu, 1994: 63).The concept of habitus comprises the most central concept in the theory of Pierre Bourdieu and has a long prehistory which begins with Aristotle and reaches as far as Nobert Elias (Chevallier \& Chauvire, 2003:73). It concerns a vested system of continuous, long term and transferable dispositions, which means that dispositions acquired in a particular field, like the family environment, have an impact on other fields too, such as the educational or professional (Corcuff, 2007:29). The habitus functions as a system of innate and organizational forms of perception, evaluation and action (Bourdieu, 1980:88-89). It constitutes a product of incorporated history which resembles transformed nature which has become instilled in the acting subject through the objective conditions of his existence and through a pedagogical shaping entirely in harmony with those conditions (Bourdieu, 2006:90 - 104; Accardo, 1991: 89 - 92; Alexander, 2000:39 - 41; Pinto, 2001:49 - 84). This internal horizon or the internal law constitutes the survival of the past in the present, as well as its perpetuation in the future (Bourdieu, 1980:91). So, according to Bourdieu the internalization of its externalized structure governs the practice of social subjects, not deterministically, but restrictively (Bourdieu, 2006:92; Coessens \& Van Berdegem, 2008:82; Baker, \& Brown, 2007). The habitus which the social subjects possess constitutes a kind of practical logic, an articulation of practical sense which orients their action within the context of a given situation in the present (Bourdieu, 2000:42). The habitus produces practices which are, on the one hand, compatible with those that the field demands on each occasion and, on the other hand, differentiated according to sex, social origin and nationality (Bourdieu, 2007b, $102-$ 103). In other words, as a structured but also structuring construction it places in the mind of the acting subjects schemes of perception and formulation which originate in the internalized and incorporated social structures, resulting in the orientation of action, the shaping of activities and the goals they aspire to (Bourdieu, 2000:156). Based on this way of looking, the practices of the acting subjects which are guided by the habitus can be approached, analysed and become comprehensible only in connection with the social conditions of its formation, as well as the social conditions of its application (Bourdieu, 2006: $92-93$ ).

According to Bourdieu, the social world, through a continuous process of socialization and shaping, constructs the body and the intellect as a 'gender social reality' socializing the biological, and biologizing the social, so that the socially constructed action of shaping which produces the gendered habits - habitus begins to appear to be a natural situation (Bourdieu, 2007b:33). From this point of view, the gender difference is based on a worldview which originates in the cultural arbitrariness of the domination of men and is registered in the social order of things (Bourdieu, 2007b:44 - 45). On the basis of these naturalized differences, society enforces and engraves 'feminine habits - gender habitus' on women through the objective conditions of their existence in a social order of things based on the aforementioned cultural arbitrariness (Bourdieu, 2007b:116 - 117). The gender identity of 
the child, which comprises a fundamental element of his social identity too, is shaped simultaneously with the reconstruction in the mind of the division of labour according to sex. In short, the gender habitus of men and women is formed in parallel with the perception and incorporation of a socially differentiated order of things for the division of labour according to sex (Bourdieu, 2006:129). Consequently, based on the shaped habitus of women which are compatible with the dominant social theory, women seek, in the world of work, 'small professions' avoiding positions of power and prestige, fully in harmony with 'their natural inclinations', in professional fields where men usually exercise power and women are restricted to offering services. This choice is the result of the harmonious meeting of the dispositions which they have incorporated and the positions which these occupy within the specific field each time such as, in this case, the educational field (Bourdieu, 2007b: 115-116). It is also the result of the symbolic violence they suffer.

Symbolic violence comprises 'a special form of coercion which can only exist with the active compliance of the acting subjects - without this signifying conscious compliance. This silent coercion is exercised unavoidably every time the objective structures meet their corresponding intellectual structures' (Panagiotopoulos, 2007:15). It concerns, in other words, a form of violence which is 'mild, imperceptible and invisible' that can be exercised through 'symbolic means of communication', producing at the same time great benefits, since symbolic violence comprises the most economical means of domination, avoiding the creation of open and violent conflicts (Bourdieu, 2007b:30; Bourdieu, 2006:205-207). This means that women's gender habitus function to direct practices even in those situations which offer women typical freedoms of choice, such as, for example, the right to vote, or the right to an education, or mainly nowadays and in this particular case, the right to choose and have access to an entire range of scientific fields and professions. Right at that moment it seems that self-exclusion and women's 'natural inclination' make an appearance and are activated as products of the gender habit habitus and symbolic violence (Bourdieu, 2007b:88).

To sum up, in Greece as well as more generally in the western world, as we mentioned above, women appear to dominate men proportionally in professions in the educational field, especially at the level of primary education and to choose the scientific field of pedagogical studies more than men do. Despite that, as far as their professional advancement is concerned, they are absent from managerial positions of power and status in the educational field, such as head of a school, school advisor, or head of local education office or authority, and they appear to be restricted to teaching work (Maragoudaki, 1997; Saiti, 2000; Tzintzidis \& Vergidis, 2003; Daraki, 2007; Taki, 2009). Consequently it becomes clear that the suitably shaped gender habits - habitus, produce differentiated practices of choice. The gender subject chooses scientific fields based on the habitus she/he possesses and which is characteristic of the particular branch of science and the social order of things (Bourdieu, 2007a, 102 - 103). In particular, the social structures become established in the institutions as in the case of the Pedagogical Department of the University of Patras, but they are also registered on the subjectivities (in this case the women - female students) in the form of gender habits - habitus (Panagiotopoulos, 2007:16). Therefore, it would be possible for one to claim that, despite the visible changes which have taken place in the social condition of women, the force of structures, which associates the division of labour and power with different fields in science and the labour market which men and women choose and are involved in, continues to dominate (Bourdieu, 2007b:191).

\section{Research Questions-Methodology}

In this paper we will explore the following research questions:

(1) What are the attitudes of the male and female students of the U.D.P.E at the University of Patras regarding the reasons for their choice of studies in the particular scientific field?

(2) Does the gender habitus influence the social subjects (male and female students in the U.D.P.E. at the University of Patras) in their choice of studies in the particular scientific field?

In order to answer these questions, we drew data from the research carried out within the context of the Research programme 'Reform of the Undergraduate Programme of Studies in U.D.P.E.'. The collection of data was carried out by use of a special questionnaire which was distributed to male and female undergraduates at the end of the academic year 2007-2008.

The total number of male and female students for the specific academic year in the U.D.P.E. at the University of Patras was 1073, of which 187 were male students (17\%) and 886 female students (83\%). From the available official data of the University of Patras, we know that during the academic year $2007-2008$, the male and female students with a normal duration of studies were 921 , of which 140 were male students $(15 \%)$ and 781 female students $(85 \%)$. In addition, the male and female students beyond the normal duration of studies were 152 , of which 47 were male students (31\%) and 105 were female students $(69 \%)$. 
The questionnaire was answered by 34 male students (11.3\%) and 260 female students $(88.7 \%)$. In total, the sample comes up to 294 male and female students, in other words approximately $28 \%$ of the total population.

To answer our research questions, we posed the male and female students a basic, open question: For what reasons did you choose to study in the scientific field of the U.D.P.E.?The students were required to answer the above question in a brief text, giving reasons for their views. After the data collection we went on to a qualitative content analysis, as we were interested in the meaning which the students attribute to their choice regarding field of studies, given that according to Hammersley, Gomm \& Woods (1994) this comprises one of the main characteristics of qualitative research.

According to Krippendorf (2004:19) the content analysis is defined as "a research technique in order to derive repeatable and valid conclusions from our data and their contexts".

Besides, qualitative content analysis is based on the presence or absence of characteristic content data and is not interested simply in the content of the communication, but in the reflection of deeper phenomena which originate there (see: Holsti, 1969 ; Berelson, 1971 ; Bardin, 1977 ; Grawitz, 1981 ; Mucchieli, 1988 ; Zagros et al, 2007). It is indicated as a diagnostic tool in qualitative research when all the material comes from open questions (Mostyn, 1985:116-118).

In addition, we systematically and empirically sought the signification of the reasons for their choices, as expressed in the writings of the male and female students, regarding the particular scientific field of studies, based on the view of Tischer et al (2000) that content analysis comprises a method within the scope of text analysis, in other words a secondary analysis of the qualitative material which in the particular case takes the form of the texts produced by the undergraduates of the U.D.P.E. (Shank, 2002:5; Iosifidis, 2008).

We then moved on to the classification of our material using as unit of analysis the issue, in other words, the basic idea which was developed in the texts in question or in the parts of the texts. The classification of our material was based on the research objective as well as on its theoretical background (Paillé \& Mucchielli, 2008: 232 - 246 ; Kyriazi, 1999: 291 - 292).

\section{Presentation and Analysis of Data}

For the purpose of the present research and based on the continuous interconnection of the theoretical model used for our data analysis, we created the following three suitable categories as well as one sub-category, through which the presentation, analysis and discussion of results was carried out:

\section{A. The profession of the teacher: a female profession}

A1. Women's offer of service through the teaching profession.

B. The choice of a temporary and sham 'Big School' by the two sexes and their prospects for immediate professional employment

C. The choice of the 'vocation' of the teacher - a controversial concept which continues to persist.

In the presentation and discussion of our data we will cite extracts as stated in students' texts because the word for word presentation of extracts from the analyzed texts supports and strengthens the interpretative attempt in "qualitative" research (Krippendorf, 2004:88). We notice also that, within the context of qualitative content analysis, emphasis has been given on the presence or absence of characteristic elements and not on the frequency of items, something that constitutes characteristic element of the qualitative content analysis (Grawitz, 2006:185).

\section{A. The profession of the teacher: a female profession}

The percentage of women who received a degree in the specific scientific field across all of the University Departments of Primary Education in Greece during the academic year 2006 was $75.90 \%$ (we should point out that the body of U.D.P.E is made up of 9 such departments, one of which is to be found in the capital, Athens, and the rest in other regions of Greece: U.D.P.E. University of the Aegean, U.D.P.E. University of Thessalonica, U.D.P.E. University of Thessaly, U.D.P.E. University of Patras, U.D.P.E. University of Thrace, U.D.P.E. University of Western Macedonia, U.D.P.E. University of Ioannina, U.D.P.E. University of Crete). The above percentage reveals without doubt the preference of women for the scientific field in question (Georgiadis, 2009). This seems to be a matter of a gender choice which also becomes clear through the discourse of the female students who answered the basic open question posed in the present research. The choice of the scientific field and the corresponding teaching profession is explained by the female research subjects as a desire to be occupied with, and a love for, children, or even as a profession which entirely 'suits' 'female nature'. So, the female students in the sample mention characteristically regarding their choice of the teaching profession that: 
"...I chose to study to be a teacher because I like to spend time with small children, and in addition it's a job for women who can raise their own children at the same time" (A2),

"...I chose it because I like to spend time with small children and in addition I want to have enough free time as a working woman" (A127),

"I opted to become a teacher because I really love little kids. They offer life to today's society" (A69).

However, a desire to be occupied with children seems to be accompanied by the desire to balance their private and public role. In their reasoning, the traditional gender constructs, with which the gender subjects of the research seem to comply entirely, are depicted.

As one female student characteristically mentions:

“...It's the most suitable profession for a woman who wants to have a family" (A36).

Another female student says:

"...I chose it because I think that the profession of the teacher is ideal for a woman as it has flexible working hours" (A115).

Strengthening the above attitude, two other female students add:

“...I've always liked this profession and I believe that it's the most ideal for a woman, provided that she loves children and has patience" (A116),

"...I think that it's the ideal profession for a woman since she can combine work and family" (A218).

Through the discourse of the female students in the U.D.P.E. in Patras, the full acceptance of their social role is revealed, they seek a balance between private and public sphere. This indicates the meeting of the women's 'objective expectations' with the gender structure of the division of labour. At exactly this point it seems to take place the harmonious meeting of the gender habitus which the social order of things has engraved on women with the profession most entirely suited to female nature, which, as is depicted in the words of the female students, is the teaching profession. This harmonious meeting of positions concerning studies, work and women's habitus hides a symbolic violence - a symbolic domination (in other words, "Power to construct a reality which aims at establishing a cognitive order: the immediate meaning of the world") which results in women's "successful' performance of jobs which suit and correspond to their virtues (Bourdieu, 1999: 239; Bourdieu, 2007b, 116). So, the teaching profession is in complete accord with the role of the woman within the family and her function as "hostess" a function which is based on traditional attitudes and is always allotted to women. Through this professional choice, women - and in the present case, female students - seem to find a solution in a profession whose social status is low, but which through a 'social contradiction' is high for women, thus excluding themselves from professions with high prestige (Maragoudaki, 2007). Hence, the 'orthodoxy' of the gender order of things is achieved, since women can simultaneously perform the role of teacher and the roles of wife and mother correctly (Mickelson, 2003). Besides, a job's status is differentiated depending on whether the job is performed by men or women and each job is 'conceived' of differently based on the gender division of its performance (Maruani \& Nicle, 1989:15; Bourdieu, 2007b:120).

It is extremely interesting the fact that when the female students refer to their choice of profession they define it as a male profession. So they refer almost always to the profession of the teacher using the masculine article, rather than the feminine. The female students in the sample, in the following statements, declare:

"I chose the profession of the teacher [using the masculine article] because it especially facilitates women" (A248),

"I like the profession of the teacher [masculine article] and that's what I wanted to follow' (A 33),

"...I believe that the profession of the teacher [masculine article] if carried out properly makes people happy" (A 149).

The gender subjects of the research (male and female students) share a 'symbolic system', language, which comprises a tool of communication and knowledge (Bourdieu, 1994:240). Bourdieu points out that "communicative relationships are always power relationships which depend on the material or symbolic power which the actors involved in those relationships have accumulated" (Bourdieu, 1999:241). So, in the discourse of the female students, the gender social relationships are depicted as relationships of power and domination. In other words, language in this particular case, legitimizes male domination, through the symbolic power of words, and faith in their legitimacy, thus confirming the gender world view (Bourdieu, 1999:244-245). The issue which arises in the particular case is that in the educational field - especially that of primary education - but also in the 
corresponding scientific field, women are overrepresented. Despite that, they seem to function as 'dominated' within the male dominated educational field, since they have fully internalized 'the rules of the game' which takes place within it, even considering them fair. Under these conditions, they function as good players, without ever doubting the game (O' Brien, \& O' Farthaigh, 2004). So, for example, they practise the profession of the teacher (considering it as male profession, as it is indicated by the masculine article they use), in other words, they teach, while they do not usually compete for administrative positions within the educational field, reproducing the dominant gender power relations (Maragoudaki, 2007). This means that the passage of gendered subjects, with parallel paths, through the educational system, in this case the U.D.P.E. at the University of Patras, does not shape similar expectations for a man and a woman, but women's professional demands are connected with imaginary representations of their social role (Panagiotopoulos, 2005:100).

\section{A.1. Women's offer of service through the teaching profession}

One of the main elements which emerges from the research data is that women associate the choice of the teaching profession with the concepts of offering service and help.

So in their statements the above concepts are clearly depicted. They characteristically state:

"It's something I've wanted since I was a child. I adore little children and I want them in my daily life and I can offer them things" (A86),

"I like it as a profession, I love children and I believe I can offer them something" (A110),

"I love children and I believe I can make a contribution to education" (A168).

The female students' answers are connected with the incorporation of the dominant world view, with the forms, in other words, of engagement with and perception of a 'sexually arranged order' which they have incorporated as women through a silent apprenticeship from their parents, their teachers or even from their classmates. This view concerns the structures of the division of labour according to sex which push and place women in jobs which, on the one hand, 'suit' them, and, on the other, comprise an 'extension of domestic functions' such as "care, services", that is, inferior auxiliary functions. The concepts of contribution and aid arise out of the habits habitus female students and are connected with and reveal the structure of the gender division of labour which is incorporated osmotically as a history that becomes a body (hexis corporelle) in the primary family one and in the subsequent secondary environment (Bourdieu, 2007b:172 - 174). Hence, the female students claim that:

"I always wanted to be a teacher, to be near to children, to help them and to educate them" (A 22).

"It has been my desire since I was small to have contact with little children, to have communication with them and attempt to help them" (A 90).

Synonymous with 'domestic functions', the concepts of help and contribution registered in the women's gender habitus, communicate with and are legitimized by the educational field, in other words the institution, preserving nevertheless the power of the structure (Bourdieu, 2007b:116, 184). Besides, as Bourdieu characteristically mentions, women are expected to be 'feminine and full of caring' (Bourdieu, 2007b:129).

B. The choice of a temporary and sham 'Big School' by the two sexes and their prospects for immediate professional employment.

In the decade of 2000 in Greece a continuous increase in demand for studies at the U.D.P.E. is noticeable. Significant factors in this increase in demand were the legislation concerning the all-day school in the reforms to the law of 1997 which played a part in the appointment of a large number of teachers, as well as the appointment of teachers as supplementary teachers. To the above factors which contribute to the demand for University Schools which guarantee immediate and permanent - at least until now - professional employment in the public sector, it should be added unemployment, which hutted and hits more so since the manifestation of the economic crisis, young male and female graduates of Universities in Greece (Georgiadis, 2009).

Indeed, in the answers of the male and female students regarding the reasons for their scientific, and consequently, professional choice, it is dominant the immediate and permanent professional employment in the public sector. On the specific issue, the attitudes of the two sexes are identical.

The female students explain their choice like this:

"I think that daily occupation with children is very attractive ...but professional employment is also quite satisfying" (A 34).

I chose it because my parents pressured me - immediate professional employment" (A 46). 
"Because I've always liked this job, but the large absorption of teachers nowadays also played a role in my choice" (A 61).

The male research subjects respond in a similar manner, focusing however more on the 'certainty' of a position in the public sector in Greece. We quote some of their characteristic responses:

"The teacher is a secure job, there's no danger of being fired" (A 24).

"I chose it because up until now it offers immediate professional employment" (A 58).

“...Economic reasons, job stability and benefits from the particular job” (A 136).

Making the reason behind his choice even clearer, another male student states:

"For a job in the public sector" (A 125).

It is interesting that some students explain their choice based on the benefits which arise from taking up the profession of teacher:

One male student, emphasizing his response notes in English:

"June, July, August: three reasons to be a teacher" (A 113).

Another adds:

"I chose to become a teacher for the good working hours and the good salaries" (A 112).

We should note that this answer was given before the economic crisis, the I.M.F. Memorandum and the subsequent salary cuts. The responses of the male and female students of the U.D.P.E. at the University of Patras reveal that during the time period of the research the U.D.P.E. in Greece were in high demand from high school graduates with an impressive increase in recent years in their entry requirements.

Past research has demonstrated the 'common' character of the U.D.P.E. in Greece, in contrast with other departmenst in the institutions of higher education (Friderikou \& Folerou - Tsarouli, 1991:56 - 57; Georgiadis, 2005). It appears that in the past the Pedagogical Departments in the collective University field of Big and Small Schools, which Bourdieu calls 'binary - dual structural bond', are included in the 'Small Schools'. However it still appears that temporarily and 'spuriously' the departments in question in Greece functioned as Big Schools (we should point out that we are using the concept loosely) or, in other words, 'as ephemerally dominant cognitive branches', in the sense that they were in high demand and had high entry requirements in the entrance examinations. So, due to the immediate professional employment of their graduates, the U.D.P.E. acquired a 'good name', became highly sought after and attractive and were approached by a 'clientele' with a different and superior socio-economic background in contrast to the past (Georgiadis, 2009; Papanis, et al., 2011). It is perhaps the only case where, through the phenomenon of the inflation of degrees without immediate professional employment prospects in recent years in Greece, the subjective hopes of the male and female students from the teaching departments of Greek universities for finding a job, matched the objective prospects for job security. Although the question of the socio-economic origin of the male and female students of the U.D.P.E. is beyond the scope of this particular work, it could be posed and remain open the question for the future direction of the Pedagogical Departments regarding this matter, but also regarding their demand from future high school graduates.

That which differentiates the discourse of the male students in the sample from that of the female students and is recorded emphatically in their responses, is that the high demand for the particular department is consistent with the choice of a 'state-oriented school', that is, a school from which graduation is linked to the securing of a position in the public sector. This is a way of thinking, a choice of studies and a professional orientation which, as it appears, continues to persist as a 'social inertia', despite the rapid social and economic changes of recent years in Greece (Kyridis, 132 - 134). The fact that the students in the sample explicitly adduce and link the choice of scientific field of studies to a position in the public sector probably reflects the pressing need of the male research subjects for job security and the exercise of a profession. Besides, based on the traditional definition of the division of social roles, it is possible to understand this pressing need for job security on the part of men, since the threat and the danger of unemployment is interpreted in a different way by women as a more 'natural' process, while for men it comprises a 'split with the team' and is lived in a dramatic way as an extremely difficult experience (Panagiotopoulos, 2005:100 - 113). So in this particular case despite the fact that we do not have evidence of differentiated social origins of the male students which would shed more light on the phenomenon, it seems that the male students seek the security of the teaching profession which also has prospects - especially for men - of promotion to managerial positions. 


\section{The choice of the 'vocation' of the teacher - a controversial concept which continues to persist.}

In the responses of the male and female students in the sample regarding the choice of scientific field and profession, we observed that both sexes define the teaching profession, which they have moreover chosen, as a 'vocation'. However the concept of 'vocation' in the discourse of the female students is connected again with the concepts of helping and giving, while in the discourse of the male students, the teaching profession is simply recorded as a 'vocation'.

In their accounts, some female students highlight the concept of vocation in the following way:

"I love children a lot and I think it's an important vocation to help them to learn" (A 70).

"I chose to study at the U.D.P.E. because I believe that the vocation of the teacher is that which can offer something, which can shape, even if only a little bit, the ethos of young children" (A 290).

In contrast to the female students, the male students in the sample used less explanatory language when referring to the 'vocation' of the teacher:

"It is a profession which is a good vocation and I've started to like the idea over the last few years" (A 144).

Or,

"I chose it because it offers immediate professional employment and for me to be a teacher is a vocation" (A 204).

The idea of promotion of teaching as a profession started in the decate of 1965-1975 and it signaled the tendency for redefining of the teaching profession (Neave 1998:224; Papanaoum, 2003:20-1). A plethora of research over the last twenty years focused on the question of whether teachers were professionals or not (Day, 2003; Hargreaves, 2000; Hilferty, 2008; Yfanti \& Fotopoulou, 2011). The teaching profession has also been characterized in comparison with other professions as a semi-profession and not as a full profession, on a level parallel with those of nursing and those which in general offer social work (Etzioni, 1969; Yfanti \& Fotopoulou, 2011). Nevertheless even today it seems that the professional role of the teacher has not been clarified, as it appears, in Greek social reality and elsewhere, and it seems to oscillate between public servant and the professional who has to face the plethora of social and economic changes which are reflected in the field of education in a rapidly changing world (Papanaoum, 2003:20).

From the above it seems that the concepts of profession and vocation are not two concepts crystallized or defined with clarity in the consciousness of the sample's male and female students.

Gender differentiation is found only in the fact that the female students use the concept of vocation as 'social contribution and help', expressing once again the 'power of the construct' in the division of labour (Bourdieu, 2007:184). In contrast, the male students simply referred to themselves as 'vocational functionaries' or as professionals, imparting an ambiguous character to the job of teaching. Here Greek reality is most probably depicted regarding the given concepts of vocation and profession in the job of the teacher, concepts not clarified but used, as the case may be, depending on the spatial and temporal context of the discourse of the representatives of the unions, in the discourse of the teachers and of the state (Yfanti \& Karatzis, 2007).

\section{Discussion and Conclusions}

In this work we turned our attention to the choice of scientific field and field of work of the male and female students of the U.D.P.E. at the University of Patras during the academic year 2007 - 2008. We attempted to detect their gender choice, through their responses, but also through the reasons for the differentiation in this choice.

From the data gathered and analyzed it became apparent that in the particular scientific branch, women proportional outnumber men in the particular University Department, as well as in the other pedagogical departments around Greece, a fact which points to its feminization, but also to the bond of the social constructs and male and female work positions within the social field (Bourdieu 2007b:192). It was also revealed the relative stability of the position of women, despite their advances over the years, since 'structural mechanisms' appear even today to succeed in ensuring the reproduction of the gender based division of labour (Bourdieu, 2007b: 156-157).

It also became apparent that the educational and professional choice of the female students in the specific University Department is constituted within a gender differentiated habitus which 'governs' their practice (choice of studies) through the limits and pressures put in place during its formation and shaping (Bourdieu, 1980: 89). So the female students in the sample choose the scientific field and profession that suits their sex - 
which is moreover registered on their consciousness as a male profession-giving priority to the creation of a family, that is, the issue of biological reproduction, as 'a natural foundation in the male-centred world view' (Bourdieu, 2007b:63).

The economic crisis manifested in recent years in Greece seems to intensify the increase in demand for U.D.P.E. due to the rise in unemployment and the prospects for immediate professional employment which their degree ensures. The U.D.P.E. became much sought after Departments, increased their reputation and differentiated their position - probably only temporarily - in the collective University field (of Big and Small schools), while almost in parallel the socio-economic background of their male and female students became more diversified (Georgiadis, 2009; Papanis et al., 2011). Nevertheless the question remains open, and probably there is no a positive answer to the issue that regards whether the demand for U.D.P.E. and the 'clientele' accepted in recent years will remain at these high levels, as far as the candidates' grades and their socio-economic origin is concerned.

The attitudes of the male and female students of the U.D.P.E. in the sample are not differentiated and are for the most part identical regarding the prospects for immediate and certain professional employment, which is revealed to be the most significant factor in choice of scientific field and profession. There is however a differentiation regarding the way in which they express their choice.

The female students seem to see their choice as an extension of the functions of their traditional role, transforming caring and giving, skills which women acquire and apply in the private sphere, into professional practice in the particular professional field of the labor market (Bourdieu, 2007b:183; Palmyri, 2006). It is a restoration of the social order of things, which is founded on the validation of male domination, and functions in relation to women through the subtle exercise of 'symbolic violence' so that they themselves confirm that by their nature they are destined for specific work, such as for example the teaching profession (Bourdieu, 2007b:74).

In contrast, the male students explain the educational and professional choice of the teaching profession as a safe choice for securing a job with immediate access to the public sector and in fact in a professional field which is connected to the contents of their studies (Kouzis, 2008:184). In their discourse, the attitude that job security is directly linked to the tertiary sector through which they can quickly and easily avoid the race for a stable job, is obvious (Panagiotopoulos, \& Thanos, 2008:41).

Finally, it appeared that the job of the teacher is depicted in the attitudes of the male and female students in the sample more as a vocation and less as a profession. However, even here the different and gender approach to the concept of vocation is evident, since the female students approach and explain it with statements such as: vocation - help, or vocation - contribution, expressing their 'early experiences' from the family environment regarding the sex based division of labor which is registered in language (Bourdieu, 2007b:158). Nowadays we could say that 'male domination' is no longer ruled by the obvious.

However the fundamental contrast between the hard (men) and the soft (women) as a form of gender choices in the scientific field and in the division of labour continues to persist (Bourdieu, 2007b:189; Panagiotopoulos, 1998).

In conclusion, it seems that in the case of the U.D.P.E at the University of Patras, a suitable 'clientele' is recruited and over-represented, a clientele whose habits - habitus harmoniously meet the gender character of the particular scientific field, which is however dominated by men, and the primary teacher bond, which are depicted and persist over time in the gender based division of labor, even today (Bourdieu \& Passeron, 1996:127). The research data, particularly in the western world, reveal, on the one hand, the penetration of women into male dominated fields, but at the same time the reality that 'traditional priorities' continue to exist regarding the choice of traditional women's professions (Frosi, 2010: 21). Family and school continue to socialize the gendered subjects with patriarchal avowals that are 'registered in their hierarchical-patriarchal constructs' (Bourdieu, 2007b:160). It is likely that the sensitizing and informing of young teachers studying in the country's Pedagogical Departments, through lessons which touch upon the equality of the sexes, could constitute the beginning of a painful and drawn out period of change in the crystallized and entrenched ways of thinking (Kantartzi, \& Anthopoulos, 2006).

\section{References}

Accardo, A. (1991). Initiation a la sociologie - une lecture de Bourdieu. Bourdeux: Le Mascaret.

Alexander, J. (2000). La reduction Critique de Bourdieu. Paris: Les editions du cerf. 
Anagnostopoulou, M., Arvaniti, I., \& Kantartzi, E. (2008). The views of male teachers on their undertaking of teaching the first year of primary school. Contemporary education, 155, 113-128. (in Greek).

Antoniou, H. (2002). The training of Greek teachers (1828 - 2000). Athens: Ellinika Grammata.

Apple, M., \& Jungck, S. (2008). You don't need to be a teacher to teach this unit: Teaching, technology and control in the classroom. In A. Hargreaves, \& M. Fullan, The development of teachers. Athens: Patakis, pp. $42-76$.

Arnot, M. (2006). Reproducing gender. Athens: Metaichmio.

Avdela, E. (1990). Female public sector employees: Gender based division of labour in the public sector 1908 1955. Athens: Research and Education Institute of the Commercial bank of Greece.

Baker, S., \& Brown, B. (2007). Images of excellence: Constructions of institutional prestige and reflections on the university choice process. British Journal of Sociology of Education, 28(3), 377-391. http://dx.doi.org/10.1080/01425690701253455

Bardin, L. (1977). L' Analyse de contenu. Paris: Puf.

Bourdieu, P. (1980). Le sens pratique. Paris: Minuit.

Bourdieu, P. (1989). La noblesse d'etat - Grandes ecoles et esprit de corps. Paris: Les edition de minuit.

Bourdieu, P. (1994). Sociology texts. Athens: Delfini.

Bourdieu, P. (1999). Language \& Symbolic Power. Athens: Kardamitsa.

Bourdieu, P. (2000). Practical Reason. On the Theory of Action. Athens: Plethron.

Bourdieu, P. (2006). The logic of practice. Athens: Alexandreia.

Bourdieu, P. (2007a). The science of science and reflexivity. Athens: Patakis.

Bourdieu, P. (2007b). Masculine domination. Patakis.

Bourdieu, P., \& Passerron, J. C. (1996). The Inheritors. Athens: Kardamitsa.

Bourdieu, P., \& Wacquant, L. J. D. (1992). Reponses. Pour une anthropologie reflexive. Paris: Le Seuil.

Coessens, K., \& Van Bendegem, J. P. (2008). Cultural Capital as Educational capital - the Need for Reflection on Educationalization of Cultural Taste. Educational Research, 3, 79-95. http://dx.doi.org/10.1007/978-1-4020-9724-9_6

Daraki, E. (2007). Educational leadership and gender. Athens: Epikentro.

Day, C. (2003). Developing teachers. Athens: imprimatur.

Dehaene, J. L. (1995). La societe de l'information. Cles pour une ere nouvelle. Brussels:

Etzioni, A. (Ed.). (1969). The semi-professions and their organization: Teachers, nurses, social workers. London: Collier - Macmillan.

Evans, M. (2004). Gender and Social Theory. Athens: Metaichmio.

Fournaraki, E. (1987). The Education and Upbringing of girls. Greek concerns (1830-1910). An Anthology. Athens: The Historical Archives of Greek Youth-General Secretary of the New Generation.

Freiderikou, A., \& Folerou Tserouli, F. (1991). Teachers in the primary school. Athens: Ypsilon.

Frosi, L. L. (2010). The genders in the school and in the discourse of the teachers. Athens: Topos.

Georgiadis, N. (2009). The increase in demand for the Primary Education Teaching Departments and the socio-economic characteristics of the students in them (2000 - 2006). Contemporary Education, 156, 61-90.

Georgiadis, N. M. (2005). An investigation of the socio-economic origin of students in the Primary Education Teaching Departments (1994 - 2000). Contemporary Education, 143, 33-52. (in Greek).

Giddens, A. (2000). Sociology. Athens: Gutenberg.

Grawitz, M. (2006). Methods of Social Sciences, vol. II, (translated in Greek by E. Asteriou), Athens, Odysseas.

Grawitz, M. (1981). Méthodes des Sciences Socials. Paris: Dalloz.

Grosser, K. (2009). Corporate social responsibility and gender equality: Women as stakeholders and the European Union sustainability strategy. Business Ethics: A European Review, 18(3), 290-307. http://dx.doi.org/10.1111/j.1467-8608.2009.01564.x 
Hammersley, M., Gomm, P., \& Woods, P. (1997). M. A. in education. Educational research methods. Milton Keynes: The Open University Press.

Hargreaves, A. (2000). Four ages of professionalism and professional learning. Teachers and Teaching: Theory and Practice, 6(2), 151-182. http://dx.doi.org/10.1080/713698714

Hilferty, F. (2008). Theorising teacher professionalism as an enacted discourse of power. British Journal of Sociology of Education, 29(2), 161-173. http://dx.doi.org/10.1080/01425690701837521

Holsti, Ole R. (1969). Content Analysis for the Social Sciences and the Humanities. Reading, MA: Addison-Wesley.

Iosifidis, Th. (2008). Qualitative research methods in the Social Sciences. Athens: Kritiki.

Kantartzi, E., \& Anthopoulos, K. (2006). The participation of the two sexes in the staffing of Primary Education. Retrieved March 17, 2012, from http://www.pi-schools.gr/download/publications/epitheorisi/teyxos11/f3.pdf

Kergoat, D. (2008). Social relations and the gendered distribution of labour. In M. Maruani (Ed.), Women, gender, societies. Athens: Metaichmio.

Kladouchou, E. (2010). Education and gender in Greece: Conceptualizations ofgender in the field of Sociology of Education. In B. Kantsa, B. Moutafi, \& E. Papataxiarhis, Gender and social sciences in Greece. Athens: Alexandreia.

Koulaidis, B. (2006). An impression of the education system at the level of the school unit. Athens: Centre for Education Research.

Kouzis, G. (2008). First experiences in the labour market: The certainty of uncertainty. In Nickos Panayotopoulos (Ed.), The disenchanting of the world (pp. 183-226). Athens: Polytropon.

Kripendorff, K. (2004). Content Analysis. An Introduction to Its Methodology. Thousant Oaks: Sage Publications.

Kyriazi, N. (1999). Sociological research. Athens: Ellinika Grammata.

Kyridis, A. (2003). Inequality in Greek education and university access (1955-1985). Athens: Gutenberg.

Maragoudaki, E. (2007). Administrative positions and educational responsibility in General Education: Female teachers and the 'glass ceiling'. In Eleni Maragoudaki (Ed.), Essays. Thessalonica: LITHOGRAPHIA (pp. 63-86). Collective study within the framework of the project Production of additional teaching material for the introduction of topics regarding the sexes in the education process (EPEAEK II, Act 4.1.1.d), realized by the Teaching Department, University of Ioannina.

Maragoudaki, E. (1997). Women teach, men manage. In Deliyanni, B., \& Ziogou, S. (Eds), Gender and school practice (pp. 258-292) (Collection of Proposals), Thessalonica: Vanias.

Maratou - Alibranti, L. (2007). Old and new professions: An overview from the point of view of gender, 19th 20th century, in H. Vitsilaki and P. Fokiali, Gender and employment. Athens: Atrapos.

Maratou - Alibranti, L., Daphna, K., Yannakopoulou, L., Kyperi, Z., \& Repa, P. (2002). Greece, women and science: National Report. Retrieved from http:www.gsrt.gr/default.asp?FILE=items/1646/149

Marouani, M., \& Nicole, C. (1989). Au Labeur des dames. Metiers masculins, employs feminins. Paris: Syros/Alternatives.

Meron, M. (2008). Women and professions: Equal participation is still a long way off. In M. Maruani (Ed.), Women, gender, societies. Athens: Metaichmio.

Mickelson, R. A. (2003). Gender, Bourdieu and the Anomaly of Women's Achievement Redux. Sociology of Education, 76(4), 373-375.

Moren, E. (2000). The seven key knowledges for the education of the future. Athens: Twenty-first editions.

Mostyn, B. (1985). The analysis of Qualitative Research Data: A Dynamic Approach. In M. Brenner et al (Eds), The research interview. Academic Press, 115-145.

Mucchieli, R. (1988). L' Analyse de contenu des documents et des communications. Paris: Les Editions ESF.

Neave, G. (1998). The teachers. Athens: Ekphrasi. 
Nickel, H. M. (2010). The change in work and the professional integration of women. In N. Vaiou, \& M. Stratigaki (Eds.), gender @ research. Athens: Metaichmio.

O'Brien, S., \& O'Farthaigh, M. (2004). Bringing in Bourdieu's theory of Social Capital: Renewing Learning Partnership Approaches to Social Inclusion. ESAI Annual Conference, NUI Maynooth., April, 1- 3, 2004.

Paille, P., \& Mucchielli, A. (2008). L'analyse qualitative en sciences humaines et sociales. Paris: Armand Colin.

Palmiri, N. (2006). The feminization of the teaching profession. Interpretations and implications. Retrieved April 15, 2012, from http://pek.org.cy/Proceedings_2006/8.\%20kefalaio\%208\%20Diaforetikotita\%20kai\%20ekpaidefsi/8.7.\%2 0N.\%20Palmiri.pdf

Panayotopoulos, N. (1998). Les grandes écoles d'un petit pays. Les études a l'étranger: Le cas de la Grece. Actes de la recherche en sciences sociales (pp. 121-122), pp. 77-91.

Panayotopoulos, N. (2005). The anguish of the unemployed. Athens: Polytropon.

Panayotopoulos, N. (2007). "Symbolic violence and social nature" in Bourdieu, P. Masculine Domination. Athens: Pataki.

Panayotopoulos, N., \& Thanos, Th. (2008). The time to understand an unfair game. In Nickos Panayotopoulos (Ed.), The disenchanting of the world (pp. 37-72). Athens: Polytropon.

Papanaoum, Z. (2003). The Profession of the Teacher. Athens: imprimatur.

Papanis, E., Viki, A., \& Balasa, A. (2011). The motives of students in Teaching Departments regarding their choice of the teaching profession. Contemporary Education, 167, 125-142.

Pinto, L. (2002). Pierre Bourdieu et la theorie du monde social. Paris: Editions Albin.

Ready, D., \& Ball, S.J. (2000). Essentials of female Management. Women's Ways of Working in the Market Place? Educational Management Administration Leadership, 28(2), 145-159.

Reppa, A. (2000). Under representation of women in the centres for the taking on of power in the School Unit Saki Karagiorga. Constructs of power in Greece today. Athens: Saki Karagiorga Institute.

Saiti, A. (2000). Female teachers and school administration in Greece. Education Issues, 57(8), 150-163 (in Greek).

Shank, G. (2002). Qualitative Research. A Personal Skills Approach. New Jersey: Merril Prentice Hall.

Sianou - Kyrgiou, E. (2010). From the university to the labour market. Athens: Metaichmio.

Sianou - Kyrgiou, E. (2007). Choice of studies for higher education and inequality of the sexes. In E. Maragoudaki (Eds.), Book - Essays, Ioannina: School of Education, Department of Philosophy, Education and Psychology, University of Ioannina, pp. 63-77.

Smith, J. (2004). Male primary teachers: disadvantaged or advantaged? Paper presented to the Australian Association for Research in Education Conference, Melbourne, December.

Stratigaki, M. (2007). The gender of social policy. Athens: Metaichmio.

Taki, B. (2009). Gendered absence. Athens: Gutenberg.

Tischer, S., Meyer, M., Wodak, R., \& Vetter, E. (2000). Methods of Text and Discourse Analysis. (Translated by Jenner, B.). London, Thousand Oaks - California: Sage.

Tsaousis, D. (2010). The community of knowledge. Athens: Gutenberg.

Tzitzidis, A., \& Vergidis, D. (2003). Women's career and post-graduate studies in Primary Education. Contemporary Education, 133, 19-28.

Varika, E. (1987). The uprising of the ladies: The birth of a feminist consciousness in Greece 1833 - 1907. Athens: Research and Education Institute of the Commercial Bank of Greece.

Walby, S. (2004). The European Union and Gender Equality: Emergent Varieties of Gender Regime. Social Politics: International Studies in gender, State \& Society, 11(1), 4-29. http://dx.doi.org/10.1093/sp/jxh024

Wilson, M. (Ed.). (1997). Women in educational management - A European Perspective, London: PCP - Paul Publishing.

Witz, A. (1995). Gender and service class formation. In T. Butler, \& M. Savage (Eds.), Social Change and the Middle Classes, London: UCL Press. 
Yfanti, A., \& Fotopoulou, B. (2011). The professionalism and the professional identity of the teacher. Conceptual clarifications. In Vergidis, D., \& Yfanti, A. (Eds.), Education Policy Issues (pp. 69 - 93). Athens: Ypsilon.

Yfanti, A., \& Karatzis, I (2007). Investigating teachers' views on life-long learning in schools in Greece. Education Sciences, 1, 23-44 (in Greek).

Zagros, C., Kyridis, A., Golia, P., \& Vamvakidou, I., (2007). Greek University Students Describe the Role of Greece in the Balkans: From Equality to Superiority. Nationalities Papers: The Journal of Nationalism and Ethnicity, 35(2), 341-367.

Ziogou - Karastergiou, S. (1986). The secondary school education of girls in Greece (1830 - 1993). Athens: Historic Archive of Greek Youth - General Secretary of the New Generation.

Ziogou -Karastergiou, S. (1986). Good girls and excellent mothers: Objectives of the girls' schools and educational policy in the 19th century. Minutes of the international symposium Historicity of childhood and youth, Athens: Metaichmio, pp. 479-496. 